\title{
EFEKTIFITAS ANGKAK (BERAS MERAH) TERHADAP PENINGKATAN KADAR TROMBOSIT PADA PENDERITA DBD
}

\author{
The Effect of Angkak ( Yeast Rice) to increase Platelet Levels In Patients with DHF \\ Ika Arum Dewi Satiti, \\ Email Korespondensi : ikaarumds@gmail.com
}

\begin{abstract}
Background: Dengue Hemorrhagic Fever (DHF) is an infectious disease caused by dengue virus, transmitted through the bite of Aedes aegypti and Aedes albopictus. DHF shows a variety of clinical and laboratory manifestations, one of which is a manifestation of bleeding caused by a decrease in the number of platelets. DBD Treatment is supportive with the aim to improve the circulation in a short time and prevent more serious complications. One of the traditional medicine that can be used to raise the platelet count is red yeast rice.

Objective: Identify differences Of platelet levels in DHF patients with and without the consumption of red yeast rice in inpatient health centers Kediri.

Methods: Descriptive cross sectional analytic approach. The population was hospitalized dengue patients in health centers Ngadiluwih and Kandangan Kediri with the number of 40 samples through medical records. The big difference in platelet levels DHF patients with and without the consumption of red yeast rice was tested by independent t-test.

Results of the study: There are two results in this research that the research results of the test dependent and independent $t$ test. T-dependent test results showed a significant difference between the levels of the first and second platelet MRS good on DHF patients with and without the consumption of red yeast rice consumption of red yeast rice with $p 0.000(p<0.005)$. Results of independent t test showed no significant difference in platelet levels MRS second day of DHF patients with and without the consumption of red yeast rice with $p 0.000(p<0.005)$. Where the DHF patients with platelet levels higher than the consumption of red yeast rice without the consumption of red yeast rice.

Conclusion: There are differences in the levels of platelet first and second day MRS in patients with DHF with red yeast rice consumption and without consumption of red yeast rice, and there are differences in platelet levels MRS second day of DHF patients with and without the consumption of red yeast rice.
\end{abstract}

Keywords : DHF, Red Yeast Rice, Platelet levels . 


\section{ABSTRAK}

Latar belakang: Demam Berdarah Dengue (DBD) merupakan penyakit infeksi virus dengue yang ditularkan melalui gigitan nyamuk Aedes aegepty dan Aedes Albopictus. DBD menunjukkan berbagai manifestasi klinis dan laboratoris, salah satunya adalah manifestasi perdarahan yang disebabkan oleh penurunan jumlah trombosit. Pengobatan DBD bersifat suportif dengan tujuan untuk memperbaiki sirkulasi dalam waktu yang cepat dan mencegah timbulnya komplikasi yang lebih berat. Salah satu pengobatan tradisional yang bisa digunakan untuk menaikkan jumlah trombosit adalah angkak.

Tujuan penelitian: Mengetahuai adanya perbedaan kadar trombosit penderita DBD dengan dan tanpa konsumsi angkak di puskesmas rawat inap Kediri.

Metode penelitian : Deskriptif analitik dengan pendekatan secara crossectional. Populasi adalah pasien DBD rawat inap di Puskesmas Kandangan dan Ngadiluwih Kediri dengan jumlah 40 sampel melalui rekam medik. Adanya perbedaan kadar trombosit penderita DBD dengan dan tanpa konsumsi angkak diuji dengan uji t-independent.

Hasil penelitian: Didapatkan dua hasil penelitian yaitu hasil penelitian yang diperoleh dari uji $\mathrm{t}$ dependent dan uji $\mathrm{t}$ independent. Hasil uji t-dependent menunjukkan adanya perbedaan yang signifikan antara kadar trombosit hari pertama dan kedua MRS baik pada penderita DBD dengan konsumsi angkak maupun tanpa konsumsi angkak dengan $p$ sebesar 0,000 ( $<<0,005)$. Hasil uji $t$ independent menujukkan adanya perbedaan yang signifikan pada kadar trombosit hari kedua MRS penderita DBD dengan dan tanpa konsumsi angkak dengan p sebesar 0,000 $(\mathrm{p}<0,005)$. Dimana kadar trombosit penderita DBD dengan konsumsi angkak lebih tinggi dibandingkan tanpa konsumsi angkak.

Kesimpulan: Terdapat perbedaan kadar trombosit hari pertama dan kedua MRS pada penderita DBD dengan konsumsi angkak maupun dengan tanpa konsumsi angkak serta terdapat perbedaan kadar trombosit hari kedua MRS penderita DBD dengan dan tanpa konsumsi angkak.

Kata kunci: DBD, Angkak, Kadar trombosit.

\section{PENDAHULUAN}

Demam Berdarah Dengue (DBD) adalah penyakit di daerah tropis yang ditularkan oleh virus Dengue (arbovirus) dan masuk ke dalam tubuh manusia melalui gigitan nyamuk Aedes Aegypti dan Aedes Albopictus (Brooker, 2001). Sering Demam Berdarah Dengue menjadi wabah penyakit di suatu daerah, terutama di daerah yang memiliki sanitasi/kebersihan lingkungan yang rendah. Puncak jumlah kasus Demam Berdarah Dengue berbeda di tiap daerah dan umumnya di Indonesia meningkat pada musim hujan, dimulai sejak bulan Desember sampai bulan April pada setiap tahunnya ${ }^{1}$.

Sejak Januari sampai dengan 5 Maret 2004 total kasus DBD di seluruh provinsi indonesia sudah mencapai 26.015, dengan jumlah kematian sebanyak 389 orang (Case Fatality Rate $(\mathrm{CFR})=1,53 \%$ ). Kasus tertinggi terdapat di Propinsi DKI Jakarta (11.534 orang) sedangkan CFR tertinggi terdapat di Propinsi NTT (3,96\%), (Depkes RI, 2004). Tahun 2007 di seluruh Indonesia terdapat 15.005 kasus dan menyebabkan 252 orang yang meninggal dunia. Kasus terbanyak pada bulan januari 2007 terdapat di Jawa Barat, Jawa Tengah, Jawa Timur ${ }^{3}$.

Berdasarkan data Dinas Kesehatan (Dinkes) Jawa Timur, jumlah kasus DBD selama 2010 lebih banyak dibanding 2009. Tahun 2010, tercatat ada 26.059 penderita DBD atau 70 orang per 100 ribu penduduk. Jumlah tersebut tergolong tinggi. Sebab, pada 2009, jumlah kasus sebanyak 18.631 penderita atau 50 orang per 100 ribu penduduk. Padahal, target nasional yakni 55 penderita per 100 ribu penduduk. Tingginya angka DBD ini tidak terjadi di seluruh kabupaten/kota di Jawa Timur. Hanya 18 kabupaten/kota dengan angka kesakitan DBD yang tinggi atau lebih dari 55 orang per 100 ribu penduduk. Kasus tertinggi terdapat di Kota Probolinggo dan Kota 
Kediri $^{3}$. Hal ini menjadi alasan bagi peneliti untuk melakukan penelitian Kabupaten Kediri.

Temuan yang hampir selalu dijumpai pada DBD adalah trombositopenia (WHO), yaitu dimana keadaan dimana hitung trombosit darah tepi ditemukan sebesar $\leq 100.000 / \mathrm{mm} 3$ (Samsi, 2000). Trombositopenia dan gangguan fungsi trombosit merupakan faktor yang berperan penting terhadap manifestasi perdarahan pada DBD ${ }^{4}$. Ketika terjadi keadaan trombositopenia jika pertolongan tidak segera diberikan, maka penderita DBD bisa sampai jatuh dalam kondisi syok dan mengalami komplikasi ${ }^{5}$.

Pengobatan suportif yang bersifat tradisional bisa dijadikan pilihan alternatif untuk mengatasi trombositopenia. Angkak merupakan salah satu obat tradisional yang dianggap mampu meningkatkan jumlah trombosit secara alamiah. Secara empiris, banyak yang sudah membuktikan bahwa pasien DBD yang mengkonsumsi angkak mengalami peningkatan trombosit secara cepat dibandingkan dengan pasien yang tidak mengkonsumsi angak ${ }^{1}$.

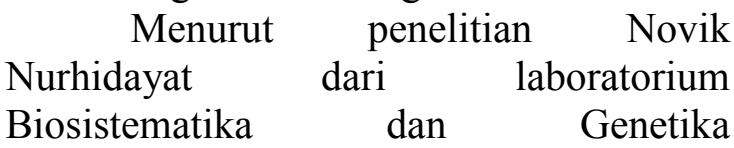
Mikroorganisme, Puslit Biologi LIPI dari Bogor pemberian angkak isolat Monascus Purpureus Jmb A pada tikus wistar putih laboratorium ternyata mengindikasikan adanya peningkatan jumlah trombosit ${ }^{6}$.

Meskipun sudah ada bukti empiris dan beberapa penelitian pada hewan coba yang membuktikan bahwa angkak mampu meningkatkan kadar trombosit, para ahli menyatakan bahwa penelitian tentang angkak masih dibutuhkan untuk mengetahui efektifitas penggunaan angkak pada manusia ${ }^{7}$. Oleh karena itu peneliti tertarik untuk mengetahui apakah ada perbedaan perubahan kadar trombosit pada penderita DBD yang mengkonsumsi angkak dan tidak mengkonsumsi angkak.

Penelitian ini dilakukan di

puskesmas Kandangan dan puskesmas Ngadiluwih Kabupaten Kediri dikarenakan pada dua puskesmas tersebut telah dilengkapi dengan fasilitas rawat inap.
Kadar trombosit pada penderita DBD juga diperiksa setiap hari, sehingga data kadar trombosit pada pasien bisa diperoleh dengan mudah. Jumlah pasien yang menjalani rawat inap juga cukup banyak. Selain itu pada puskesmas Kandangan telah menggunakan angkak sebagai konsumsi rutin pada sebagian penderita DBD.

\section{METODE PENELITIAN}

Penelitian ini menggunakan metode Cross Sectional Retrospektif yang bersifat Observasional Analitik .Populasi dari penelitian ini adalah pasien Demam Berdarah Dengue (DBD) yang dirawat inap di puskesmas Kandangan dan Ngadiluwih kabupaten Kediri periode JanuariDesember 2010. Data diperoleh dari rekam medik dengan kadar data awal sebanyak 273 orang. Dimana 123 orang berasal dari puskesmas Kandangan dan 150 orang dari puskesmas Ngadiuwih Kediri. Kemudian didapatkan sampel yang memenuhi kriteria inklusi sebesar 40 orang yaitu 18 orang dari puskesmas Kandangan dan 22 orang dari puskesmas Ngadiluwih. Sebanyak 133 orang dieksklusi karena termasuk salah satu atau lebih dari kriteria berikut ini yaitu, sebanyak 64 orang dengan umur $<18$ tahun, 48 orang dengan kadar awal trombosit $>$ $100.000 / \mathrm{mm}^{3}$, dan 29 orang dengan data rekam medis yang kurang (tidak ada data kadar trombosit hari kedua MRS).

Data diambil pada awal dan hari kedua pasien MRS. Trombosit diambil pada hari kedua pasien MRS dikarenakan pada penelitian sebelumnya mengenai pemberian angkak, juga disebutkan bahwa kadar tertinggi trombosit penderita DBD berada pada saat 2 hari setelah pemberian angkak 8 .

\section{HASIL PENELITIAN}

\section{Deskripsi Karakteristik Responden}

Analisis deskriptif ini
dimaksudkan untuk menggambarkan distribusi dari karakteristik responden. Berdasarkan hasil observasi untuk memberikan gambaran secara umum mengenai kondisi pasien Demam Berdarah Dengue (DBD) yang dirawat inap di puskesmas Kandangan dan Ngadiluwih 
Kabupaten Kediri, diperoleh informasi mengenai usia, jenis kelamin, dan bulan ketika mereka masuk puskesmas. Hasil rekapitulasi distribusi frekuensi yang terkumpul dari rekam medik tentang karakteristik responden tersebut dapat dilihat pada tabel berikut.

Tabel 1. Deskripsi Karakteristik Responden Berdasarkan Usia

\begin{tabular}{ccc}
\hline Usia & Frekuensi & Persentase \\
\hline$<\mathbf{2 0}$ thn & 21 & $52,50 \%$ \\
$\mathbf{2 0}-<\mathbf{3 0}$ thn & 7 & $17,50 \%$ \\
$\mathbf{3 0}-<\mathbf{4 0}$ thn & 5 & $12,50 \%$ \\
$\mathbf{4 0}-<\mathbf{5 0}$ thn & 6 & $15,00 \%$ \\
$>\mathbf{5 0}$ thn & 1 & $2,50 \%$ \\
Jumlah & 40 & $100 \%$ \\
\hline
\end{tabular}

Sumber : Data primer yang diolah

Berdasarkan hasil penelitian dapat diketahui bahwa para pasien Demam Berdarah Dengue (DBD) yang dirawat inap di puskesmas Kandangan dan Ngadiluwih Kabupaten Kediri berusia di bawah 20 tahun ada sebanyak 21 orang $(52,50 \%)$, usia $20-30$ tahun ada sebanyak 7 orang $(17,5 \%)$, usia $30-40$ tahun ada sebanyak 5 orang $(12,5 \%)$, usia $40-50$ tahun ada sebanyak 6 orang (15\%), dan usia di atas 50 tahun ada sebanyak 1 orang $(2,5 \%)$. Melalui tabel di atas menunjukkan bahwa pasien Demam Berdarah Dengue (DBD) yang dirawat inap di puskesmas Kandangan dan Ngadiluwih Kabupaten Kediri paling banyak berusia di bawah 20 tahun. Namun pada kisaran usia lebih dari 20 tahun tetap mempunyai resiko terserang DBD meskipun dengan persentase yang bervariasi.

\section{Tabel 2. Deskripsi Karakteristik} Responden Berdasarkan Jenis Kelamin

\begin{tabular}{ccc}
\hline Jenis kelamin & Frekuensi & Persentase \\
\hline Perempuan & 20 & $50 \%$ \\
Laki-laki & 20 & $50 \%$ \\
Jumlah & 40 & $100 \%$ \\
\hline
\end{tabular}

Sumber : Data primer yang diolah Jenis kelamin dari para pasien Demam Berdarah Dengue (DBD) yang dirawat inap di puskesmas Kandangan dan Ngadiluwih Kabupaten Kediri dapat diketahui bahwa 50\% laki - laki dan 50\% wanita. Berdasarkan tabel di atas menunjukkan bahwa pasien Demam Berdarah Dengue (DBD) yang dirawat inap di puskesmas Kandangan dan Ngadiluwih Kabupaten Kediri setengahnya adalah wanita dan setengahnya adalah laki - laki. Dengan kata lain baik wanita maupun laki laki mempunyaoi resiko yang sama terserang DBD.

Tabel 3. Deskripsi Musim DBD Berdasarkan Jumlah Responden

\begin{tabular}{ccc}
\hline Bulan & Frekuensi & Persentase \\
\hline Januari & 6 & $15 \%$ \\
Februari & 6 & $15 \%$ \\
Maret & 12 & $30 \%$ \\
April & 4 & $10 \%$ \\
Mei & 1 & $2,5 \%$ \\
Juni & 5 & $12,5 \%$ \\
Oktober & 3 & $7,5 \%$ \\
Desember & 3 & $7,5 \%$ \\
Jumlah & 40 & $100 \%$ \\
\hline Sumber : Data
\end{tabular}

Sumber : Data primer yang diolah

Berdasarkan hasil penelitian dapat diketahui bahwa pada pasien DBD yang dirawat inap di puskesmas Kandangan dan Ngadiluwih Kabupaten Kediri paling banyak terjadi pada bulan Maret yaitu sebanyak 12 orang (30\%), 15\% masuk pada bulan Januari dan Februari, 12,5\% masuk pada bulan Juni, sedangkan pasien lainnya masuk pada bulan lainnya dengan total $27,5 \%$. Melalui tabel di atas menunjukkan bahwa jumlah pasien DBD yang dirawat inap di puskesmas Kandangan dan Ngadiluwih Kabupaten Kediri paling banyak adalah pada bulan Maret, sedangkan pada bulan - bulan lainnya mempunyai frekuensi yang bervariasi.

Deskripsi Jumlah Trombosit Pasien DBD Awal MRS (Sebelum Diterapi)

Jumlah trombosit pasien DBD di puskesmas Kandangan dan Ngadiluwih Kabupaten Kediri sebelum mendapatkan terapi angkak dan mendapatkan terapi konservatif, dapat diuraikan sebagai berikut. 
Tabel 4. Deskripsi Jumlah Trombosit Pasien DBD Saat Sebelum Diterapi
Tabel 6. Deskripsi Jumlah Trombosit Pasien DBD Hari kedua MRS (Setelah Diterapi)

\begin{tabular}{llll}
\hline $\begin{array}{l}\text { Hasil } \\
\text { Rekam } \\
\text { Medik }\end{array}$ & $\begin{array}{l}\text { Mean } \\
\text { Standar } \\
\text { Deviasi }\end{array}$ & $\begin{array}{l}\text { Batas } \\
\text { Terendah } \\
\text { (Mean }- \\
\text { Std) }\end{array}$ & $\begin{array}{l}\text { Bat } \\
\text { Te } \\
\text { (M } \\
\text { Std) }\end{array}$ \\
\hline Trombosit & $83.100 \pm$ & $70.480,545$ & 95.71 \\
& & \\
\multicolumn{4}{c}{ Sumber : Data primer yang diolah } \\
Berdasarkan hasil penelitian pada
\end{tabular}

Tabel 4. menunjukkan bahwa dari 40 orang pasien, rata - rata mempunyai jumlah trombosit dengan batas terendah 70480,545 $\mathrm{mm}^{3}$ dan tertinggi $95719,455 \mathrm{~mm}^{3}$.

Jumlah trombosit tersebut jika dibedakan berdasarkan rencana pemberian terapi, maka dapat dijelaskan sebagai berikut.

Tabel 5. Deskripsi Jumlah Trombosit Pasien DBD Berdasarkan Rencana Pemberian Terapi

\begin{tabular}{|c|c|c|}
\hline $\begin{array}{l}\text { Hasil } \\
\text { Rekam } \\
\text { Medik }\end{array}$ & $\begin{array}{l}\text { Pre Terapi } \\
\text { Konservatif } \\
\text { (tanpa } \\
\text { angkak) } \\
\text { (Mean } \\
\pm \text { Std) }\end{array}$ & $\begin{array}{l}\text { Pre Terapi } \\
\text { Angkak } \\
(\text { Mean } \\
\pm \text { Std) }\end{array}$ \\
\hline Trombosit & $\begin{array}{c}84.600 \pm \\
12.100,946\end{array}$ & $\begin{array}{c}81.200 \pm \\
13.320,705\end{array}$ \\
\hline
\end{tabular}

Dari Tabel 5 menunjukkan bahwa dari 22 orang pasien yang akan mendapatkan terapi konservatif rata - rata mempunyai jumlah trombosit dengan batas terendah 72.499,05 $\mathrm{mm}^{3}$ dan tertinggi $96.700,95 \mathrm{~mm}^{3}$, kemudian dari 18 orang pasien yang akan mendapatkan terapi angkak rata - rata mempunyai jumlah trombosit dengan batas terendah 67.879,30 $\mathrm{mm}^{3}$ dan tertinggi $94.520,71 \mathrm{~mm}^{3}$.

Deskriptif Jumlah Trombosit Pasien DBD Hari kedua MRS (Setelah Diterapi)

Jumlah trombosit pasien DBD di puskesmas Kandangan dan Ngadiluwih Kabupaten Kediri setelah mendapatkan terapi angkak dan mendapatkan terapi konservatif, dapat diuraikan sebagai berikut.

\begin{tabular}{|c|c|}
\hline $\begin{array}{l}\text { Pos Terapi } \\
\text { Konservatif } \\
\text { (tanpa } \\
\text { angkak) }\end{array}$ & $\begin{array}{l}\text { Pos Terapi } \\
\text { Angkak } \\
\text { (Mean } \\
\pm \text { Std) }\end{array}$ \\
\hline $\begin{array}{l}\text { (Mean } \\
\pm \text { Std) }\end{array}$ & \\
\hline
\end{tabular}

\begin{tabular}{ccc} 
Trombosit & $109.000 \pm$ & $170.000 \pm$ \\
& $21.301,434$ & $33.260,509$ \\
\hline
\end{tabular}

Sumber : Data primer yang

diolah

Dari Tabel 5.6 menunjukkan bahwa dari 22 orang pasien yang mendapatkan terapi konservatif rata - rata mempunyai jumlah trombosit dengan batas terendah $87.698,57 \mathrm{~mm}^{3}$ dan tertinggi $130.301,43 \mathrm{~mm}^{3}$, kemudian dari 18 orang pasien yang akan mendapatkan terapi angkak rata - rata mempunyai jumlah trombosit dengan batas terendah $136.739,49 \mathrm{~mm}^{3}$ dan tertinggi $203.206,51$ $\mathrm{mm}^{3}$.

Gambaran data (deskriptif) nilai rata - rata (mean) dan standar deviasi tersebut di atas digunakan untuk mengetahui dan memeriksa keadaan data secara kasar mengenai keberadaan outlier (pencilan atau data ektrim besar atau kecil). Berdasarkan output di atas tampak bahwa variabel data rekam medik berupa jumlah trombosit yang akan diuji memiliki rata rata (mean) yang lebih besar dari simpangan bakunya (standar deviasi). Hal ini mengindikasikan bahwa data hasil pengamatan tersebut tidak ada yang memencil (outlier). Sehingga berdasarkan keadaan data secara kasar tersebut dapat disimpulkan sementara bahwa data yang akan diuji dapat dikatakan berdistribusi normal, namun hal ini perlu dilakukan uji normalitas data secara statistik (hasil nomalitas ada pada lampiran). Berdasarkan hal pengujian normalitas data dengan menggunakan uji Kolmogorov - Smirnov menunjukkan nilai signifikan (p) yang lebih besar dari alpha 0,05, sehingga dapat dikatakan bahwa data yang akan diuji dengan menggunakan uji $\mathrm{T}$ - student tersebut mempunyai distribusi yang nomal. Oleh karena asumsi kenormalan distribusi 
data telah terpenuhi maka dapat dilakukan pengujian dengan uji $\mathrm{T}$ - student.

\section{Analisa Perbedaan Jumlah Trombosit Antara Pre dan Pos Terapi \\ Analisa perbedaan jumlah} trombosit antara pre dan pos terapi maka dapat dilakukan dengan menggunakan uji $\mathrm{T}$ berpasangan (paired sample t test). Adapun hasil pengujian trombosit pre dan pos terapi angkak dapat dirinci sebagai berikut.

Tabel 7. Deskripsi Perbedaan Jumlah Trombosit Antara Pre dan Pos Konsumsi Angkak

\begin{tabular}{|c|c|c|c|}
\hline $\begin{array}{c}\text { Hasil } \\
\text { Rekam } \\
\text { Medik }\end{array}$ & $\begin{array}{c}\text { Pre } \\
\text { Konsumsi } \\
\text { Angkak } \\
\text { (Awal } \\
\text { MRS) }\end{array}$ & $\begin{array}{c}\text { Pos } \\
\text { Konsumsi } \\
\text { Angkak } \\
\text { (Hari } \\
\text { kedua } \\
\text { MRS) }\end{array}$ & $\begin{array}{r}\text { Nilai } \\
\text { Signifika } \\
\text { (p-valu }\end{array}$ \\
\hline Troml & $\begin{array}{l}81.200 \pm \\
13.320,705\end{array}$ & $\begin{array}{l}170.000 \pm \\
33.260,509\end{array}$ & $\begin{array}{l}\text { thitung } \\
15,004 \\
\text { p-value } \\
0,000\end{array}$ \\
\hline
\end{tabular}

Sumber : Data primer yang diolah Berdasarkan Tabel 5.7 dari 18 orang pasien menunjukkan bahwa jumlah trombosit antara pre dan pos konsumsi angkak menunjukkan adanya perbedaan yang signifikan dengan $p$-value sebesar $0,000$ ( $p$ - value $<0,05)$, karena saat sebelum mendapatkan terapi angkak jumlah trombosit pasien rata - rata (mean) sebesar $81.200 \mathrm{~mm}^{3}$, namun setelah mendapatkan terapi angkak jumlah trombosit pasien rata - rata (mean) menjadi $170.000 \mathrm{~mm}^{3}$. Selanjutnya, hasil pengujian untuk jumlah trombosit pre dan pos terapi konservatif dapat dirinci sebagai berikut.

Tabel 8. Deskripsi Perbedaan Jumlah Trombosit Antara Pre dan Pos Terapi Konservatif

\begin{tabular}{cccc}
\hline Hasil & Pre Terapi & Pos Terapi & Nilai \\
$\begin{array}{c}\text { Rekam } \\
\text { Medik }\end{array}$ & Konservatif & Konservatif & $\begin{array}{c}\text { Signifikansi } \\
\text { (p-value) }\end{array}$
\end{tabular}

Berdasarkan Tabel 5.8 dari 22 orang pasien menunjukkan bahwa jumlah trombosit antara pre dan pos terapi konservatif menunjukkan adanya perbedaan yang signifikan dengan $p$-value sebesar 0,000 ( $p$-value $<0,05)$, karena saat sebelum mendapatkan terapi angkak jumlah trombosit pasien rata - rata (mean) sebesar $84.600 \mathrm{~mm}^{3}$, namun setelah mendapatkan terapi angkak jumlah trombosit pasien rata - rata (mean) menjadi $109.000 \mathrm{~mm}^{3}$.

\section{Analisa Perbedaan Jumlah Trombosit Antara Terapi Angkak dan Terapi} Nilai Konservatif

Berdasarkan hasil penelitian yang diperoleh tersebut, kemudian dianalisis untuk mengetahui adanya perbedaan pemberian terapi angkak dan terapi konservatif terhadap peningkatan = jumlah trombosit pada pasien DBD, yaitu dengan menggunakan uji $\mathrm{t}$ tidak bexpasangan (independent sample $t$ test) yang dilakukan sebagai berikut.

Menurut Santono (2001), pada dasarnya statistik inferensi mempelajari pengambilan keputusan tentang suatu parameter populasi (rata - rata (mean) maupun proporsi) dari sampel yang ada. Pengujian dengan menggunakan uji $\mathrm{t}$ dua sampel akan menguji apakah rata - rata (mean) dua populasi yang dibandingkan sama ataukah berbeda nyata (signifikan).

Sebelum dilakukan pengujian dengan menggunakan uji $t$, terlebih dahulu dilakukan pengujian terhadap keragaman data yang akan diuji apakah varians populasi kedua sampel tersebut sama ataukah berbeda. Uji kesamaan ragam (Homogeneity of Variances) dalam SPSS 16 dilakukan dengan mengunakan uji Levene dengan berdasarkan hasil analisis (lampiran uji $\mathrm{t}$ independent) menunjukkan bahwa data rekam medik pasien DBD di puskesmas Kandangan dan Ngadiluwih Kabupaten Kediri yang mendapat terapi

$\begin{array}{llllll}\text { Trombosit } & 84.600 \pm & 109.000 & \pm & t_{\text {hitung }}= & = \\ & 12.100,946 & 21.301,434 & 6,464 \\ & & & & \text { p-value } \\ & & & & 0,000\end{array}$
angkak dan mendapat terapi konservatif menunjukkan nilai signifikansi atas levene test yang lebih besar dari alpha 0,05 , sehingga dapat disimpulkan bahwa varians (ragam) dari data variabel tersebut tidak

Sumber : Data primer yang diolah 
berbeda secara signifikan (homogen). Dengan demikian maka dapat dilakukan pengujian lebih lanjut menggunakan uji $t$ dengan berdasarkan dari hasil analisis kesamaan ragam tadi (equal variances assumed) untuk melakukan pengambilan keputusan.

Tabel 9. Hasil Perhitungan Uji t tidak berpasangan (independent sample $t$ test) Antara Pasien yang Mendapatkan Terapi Angkak dan Konservatif

\begin{tabular}{|c|c|c|c|}
\hline $\begin{array}{l}\text { Hasil } \\
\text { Rekam } \\
\text { Medik }\end{array}$ & $\begin{array}{l}\text { Konsumsi } \\
\text { Angkak }\end{array}$ & $\begin{array}{l}\text { Terapi } \\
\text { Konservatif } \\
\text { (Tanpa } \\
\text { Anokgk) }\end{array}$ & $\begin{array}{l}\text { Nilai angkak juga menunjukkan kadar trombosit } \\
\text { signifikhnsi kedua MRS yang lebih tinggi } \\
\text { (p-valuelibandingkan pendrita DBD tanpa }\end{array}$ \\
\hline Trombosit & $\begin{array}{l}170.000 \pm \\
33.260,509\end{array}$ & $\begin{array}{l}109.000 \quad \pm \\
21.301,434\end{array}$ & $\begin{array}{l}\text { thitung sesuai dengan hasil penelitian sebelumnya } \\
7,043 \text { yang dilakukan oleh Novik di pusat } \\
\mathrm{p} \text { - valpenelitian biologi, Lembaga Ilmu } \\
0,000 \text { Pengetahuan Indonesia (LIPI) Bogor. }\end{array}$ \\
\hline $\begin{array}{l}\text { Ber } \\
\text { menunjukkar } \\
\text { antara pasie } \\
\text { angkak d } \\
\text { menunjukkar } \\
\text { signifikan de } \\
\text { p-value }<\end{array}$ & $\begin{array}{l}\text { dasarkan } \\
\text { bahwa j yang me } \\
\text { engan ter } \\
\text { adanya }\end{array}$ & $\begin{array}{l}\text { mer yang diolal } \\
\text { Tabel } 5 . \\
\text { mlah trombos } \\
\text { dapatkan tera } \\
\text { i konservat }\end{array}$ & $\begin{array}{l}\text { pemberian angkak terhadap darah tikus } \\
\text { putih (Rattus Sp.) menunjukkan adanya } \\
\text { peningkatan kadar trombosit selama masa } \\
\text { perlakuan. Dimana kadar trombosit pada } \\
\text { tikus putih (Rattus Sp.) dengan pemberian } \\
\text { angkak lebih besar dibandingkan dengan } \\
\text { kelompok kontrol (tanpa pmberian angkak) } \\
12,13,14\end{array}$ \\
\hline
\end{tabular}

peningkatan jumlah trombosit pasien yang mendapatkan terapi angkak jumlah trombosit pasien rata - rata (mean) sebesar $170.000 \mathrm{~mm}^{3}$, sedangkan pasien yang mendapatkan terapi konservatif jumlah trombosit pasien mengalami peningkatan denag rata - rata (mean) sebesar 109.000 $\mathrm{mm}^{3}$.

\section{PEMBAHASAN}

Perbedaan Kadar Trombosit Penderita DBD Dengan dan Tanpa Konsumsi Angkak Pada Hari Kedua MRS.

Berdasarkan hasil penelitian, dapat diketahui bahwa kadar trombosit pada pasien DBD post terapi konservatif lebih rendah $(109.000 \pm 21.301,434)$ dari pada pasien DBD dengan post konsumsi angkak $(170.000 \pm 33.260,509)$. Dari data uji $t$ kadar trombosit tersebut antara pasien DBD dengan dan tanpa konsumsi angkak menunjukkan perbedaan secara bermakna $(\mathrm{p}=0,00>0,05)$. Kadar trombosit penderita DBD dengan konsumsi angkak mengalami kenaikan cepat pada hari kedua MRS. Hal ini sesuai dengan penelitian yang dilakukan oleh Erwin pada awal tahun 2008 di RSUD Dr. Soetomo Surabaya yang menunjukkan bahwa pemberian angkak selama 7 hari periode sakit pada 19 penderita infeksi Dengue menunjukkan 11 penderita $(64,7 \%)$ yang memberikan respon segera setelah terapi. Rerata respon kenaikan trombosit setelah terapi sebesar 31 jam dengan tidak ditemukan efek samping 9,10,11 .

Pendrita DBD dengan konsumsi

\section{Perbedaan Kadar trombosit Awal MRS Dan Hari kedua MRS}

Berdasarkan hasil penelitian pada tabel 7 dan. 8 menunjukkan bahwa kadar trombosit antara pre dan post konsumsi angkak serta kadar trombosit antara pre dan post terapi angkak menunjukkan adanya perbedaan yang bermakna. Hal ini mengindikasikan bahwa kadar trombosit pasien setelah diberi terapi baik dengan atau tanpa konsumsi angkak dibandingkan ketika sebelum mendapatkan terapi menunjukkan adanya perbedaan yang bermakna, karena baik konsumsi angkak maupun terapi konseratif mampu meningkatkan kadar trombosit pasien DBD.

Hal ini meununjukkan bahwa konsumsi angkak dan terapi konservatif sebagai salah satu cara pengobatan bagi pasien DBD terbukti mampu memperbaiki kondisi umum pasien terutama kadar trombosit mereka dibandingkan ketika sebelum mendapat konsumsi angkak dan 
terapi konservatif. Terapi konservatif dapat meningkatkan kadar trombosit karena dasar patogenesis DBD adalah perembesan plasma, yang terjadi pada fase penurunan suhu (fase a-febris, fase kritis, fase syok) maka dasar pengobatannya adalah penggantian volume plasma yang hilang lewat pemberian cairan yang adekuat. Ketika hilangnya cairan akibat kebocoran plasma teratasi, maka volume darah akan kembali normal 15,16,20 .Sirkulasi darah normal akan mampu memproduksi faktor perangsang Mk-CSF (faktor perangsangkoloni megakariosit) interleukin dan TPO (faktor pertumbuhan dan perkembangan megakariosit) ketika kadar trombosit dalam darah menurun ${ }^{21,22 .}$.

Namun demikian, penggunaan konsumsi angkak dapat meningkatkan kadar trombosit pada pasien DBD lebih cepat daripada terapi konservatif saja (tanpa konsumsi angkak). Sebab, angkak mempunyai beberapa senyawa aktif diantaranya Monaklin $K$ yang mampu meningkatkan kadar trombosit dalam darah penderita DBD ${ }^{23,24,25}$.

\section{KESIMPULAN}

Hasil penelitian ini menunjukkan perbedaan peningkatan jumlah trombosit antara pasien DBD dengan dan tanpa konsumsi angkak, dimana pasien dengan konsumsi angkak menunjukkan peningkatan jumlah trombosit yang lebih signifikan dibandingkan pasien tanpa konsumsi angkak (P_0.000).

\section{KELEMAHAN PENELITIAN}

Dalam penelitian ini tentu masih terdapat kelemahan. Kelemahan tersebut antara lain adalah hasil penelitian ini tidak mencakup semua umur karena dimulai dari umur 18 tahun sehingga efektifitas konsumsi angkak dalam meningkatkan kadar trombosit pada anak masih belum dikethui. Kemudian faktor predisposisi dari pasien yang bisa mempengarhi kadar trombosit tidak dipertimbankan seperti peyakit penyerta dan asupan makanan serta cairan tertentu. Peneliti juga tidak mencatat hari keberapa pasien demam ketika awal MRS dan tidak melakukan pengamatan biomolekuler untuk melihat perubahan kadar trombosit melainkan hanya dari rekam medis saja.

\section{DAFTAR PUSTAKA}

Abbas AK, Lictman AH, Fober JS, 2000. Cellular and Molecular Immunology, WB Sauders Company, Philladelphia.

Agung A dan Wayan P, 2007, Pola Jumlah Trombsit Demam Berdarah Dengue, Jurnal Penyakit Dalam, Vol.8, p.216-221.

Anderson R, Wang S, Osiowy C. Activation of Endothelial Cell Via Antibdyenhanced Dengue Virus Infecition or Peripheral Blood Monocytes. Journal of Virology, 1997, 71(6): 4226-4232.

Betty S, Dharma M, Srikandi F. Produksi Konsentrat dan Bubuk Pigmen Angkak dari M onascus Purpureus Serta Stabilitas Selama Penyimpanan, Bul. Teknol. dan Industri Pangan, 1997, Vol 8, p.30-38.

Biron CA, Dalon M, Salazar-Mather TP, 2002. Innate Immunity and Viral Infections. In: Kaufmann SHE, Sher A, Ahmed R. Eds. Immunology of Infectious diseases, Wasingtons DC: ASM Press, p.139-160.

Broom AK, Smith DW, Hall RA, Johansen CA, et al. 2003. Arbvirus Infection. In :Cook $G$, Zumla A, eds. Manson's Tropical Disease. $21^{\text {st }}$ ed. Saunders, London, p.725-764.

Chaturvedi U. Cytokine Cascade in Dengue Hemmorrhagic Fever : Implication for Pathogenesis. FEMS Immunol Med Microbiol, 2000, 12(8): 183188.

Chiang W, Talavera F, Sheridan BJ, Halamka J, Brenner B. Dengue Fever,(Online),( http://www.Emedicine.com.html, diakses 28 maret 2010).

Depkes, 2005. Pedoman Tatalaksana Klinis Infeksi Dengue di Sarana Pelayanan Kesehatan, Depkes RI, Jakarta, n.p. 
Dinarello CA, Gelfand JA. 2001. Fever and Hyperthermia. In: Braunwald E, Fausi AS, Kasper DL, Hauser SL, Longo DL, Jameson JL., (Eds), Harrison's Principles of inernal Medicine. $15 \mathrm{~h}$ ed. Vol 1. New York: McGraw-Hill, p. 90-94.

Djunaedi, 2006. Demam Berdarah Dengue. Epidemiologi, Imunopatologi, patogenesis, diagnosis dan penatalaksanaannya, UMM press, Malang.

Djunaedi D, 2004, Perubahan Kadar Sitokin TNF $\alpha$, IL-1 $\beta$ dan IL-6 dan Molekul Agregasi Vwf DAN pgi2 Pada Berbagai Tingkat Trmbositopenia Pada Penyakit DBD. Disertasi. Fakultas Kedkteran Universtas Airlangga, Surabaya.

Dwi, Kristianto. Pengaruh Pemberian Konsumsi Angkak Pada Kadar Trombosit Tikus Putih (Rattus Sp.), Bioverditas, 2009, Vol. 10, p. 218-231.

Evi T, Novik N. Pengaruh Pemberian Beras yang Difermentasi oleh Monascus Purpureus Jmba Terhadap Darah Tikus Putih (Rattus Sp.) Hiperkolesterolemia, Bioverditas, 2006, Vol. 7, p. 317-321.

Erwin, Affan. Managemen Terkini DHF Fokus Pada Trombositopenia, Jurnal Penyakit Dalam, 2010, Vol.11, p.219-229.

Green S, Vaughn DW, kalayanarooj S, Early Immune Activation in Acute Dengue Ilness is Releated to Development of Plasma leakage and Disease Severity. J infect Dis, 1999, 179: 755-762.

Halstead SB. Dengue, Hematologic aspect. Seminars in Hematology, 1982, 19: p.116-131.

Hasim D. Optimizing Angkak Pigments and Lovastatin Production by Monascus Purpureus, Hayati Journal of Bioscience, 2008, Vol 15, p. 61-66.

Kurane I, Ennis F.A, 1997. Immunopathogenesis of Dengue Virus Infection. In Gubler DJ, kuno G. (Eds), Dengue and Dengue Hemorrhagic Fever, Wallingford, UK: Cab International, p. 273-290.

Livingstone PG, Kurane I, Dai LC, Modulation of The Function Of Dengue Virus Spesific Human CD8+ Cytotoxic T cell Clone by IL-2, IL-6 and TNFa. Immunol Invest, 1995, 24: 619-629.

Nimmannitya S. Dengue Haemorrhagic Fever. In: Cook G, Zulma A. Eds. Manson's Tropical Diseases. 21st ed, London: Saunders, 765-772.

Nur F. 2010. Hubungan Pemberian Beras Angkak Merah (Monascus Purpureus) Terhadap Hitung Limfosit Pada Mencit Balb/C Model Sepsis. Disertasi. Fakultas Kedokteran Universitas Negeri Sebelas Maret UNS, Solo.

Oppenheim J.J, Ruscetti F.W, 2001. Cytokines. In Parslow TG, Stites DP, Terr AL, Imbonden JB. Eds. Lange Medical Immunology. 10th ed. McGraw-Hill Companies, New York, p. 148-166.

Sylvia $\mathrm{P}$ and Loarraire WM. 2006. Patofisiologi (konsep klinis proses-proses penyakit) jilid 2, EGC, Jakarta.

Sean, W. 2006. Innate Immunity and Viral Infections. In: Kaufmann SHE, Sher A, Ahmed R. Eds. Immunology of Infectious diseases, Wasingtons DC: ASM Press, p. 159-170.

Samsi T, 2000 Dengue Hemorrhagic Fever. Diagnosis, Treatment and control, second edition, World Health Organization, Geneva.

Sarwari AR and Mackowiak PA. 1994. Pathogenesis of Fever. In: Amstrong D, Cohen J. Eds. Infectious Diseases Ist ed, Mosby, London, p.311-316.

Sharpe E, 2001, Red Yeast Rice, [online], didapat dari (http://www.delano.com/Referenc eArticles/Red-Yeast-RiceSharpe.html. diunduh 11 februari 2011). 
Sucipto, Suryo. 2007. Epidemiologi Demam Berdarah Dengue di Indonesia. Penebar Swadaya, Jakarta.

Sugijanto S dan Hariadhi S. 2006, Pola Distribusi Serotype Virus Dengue pada Beberapa Daerah Endemik di Jawa Timur dengan Kondisi Georafis Berbeda. TCD-UNAIR, Surabaya.

Sugianto D, Tatang K, Hasna w, et al. Perubahan Jumlah Trombosit pada Demam Berdarah Dengue. Cermin Dunia Kedokteran, 2000, (92) : 14-18.

Suharti C. Dengue Hemorrhagic Fever in Indonesia: the role of cytokines in plasma leakage, coagulation and fibrinolysis, Nijmegen University Press, Nijmegen, 2001, p.7-23.

Suhendro, Nainggolan L, Chen K, et al, 2006. Demam Berdarah Dengue. In: Ilmu Penyakit Dalam. Jilid 1, ist edition, Pusat Penerbitan Departemen Ilmu Penyakit Dalam FK UI, Jakarta, p.1731-1735.

Szomolanyi-Tsuda E, Brehm A, Welsh RM, 2002, Acquired immunity againts viral infection, in: kaufmann SHE, She A, Ahmed R. (Eds). Immunology of infectious diseases, ASM Press, Washingtons DC, p. 247-265.

Damisi T. 2008, Sehat dengan Angkak, HATA Publishing, Jakarta.

Tisnadjaja D, 2006, Bebas Kolesterol dan Demam Berdarah dengan Angkak, Penebar Swadaya, Jakarta.

WHO. Dengue Hemorrhagic Fever: diagnosis, treatment, prevention and control. 2nd ed, 1997, WHO, Geneva, p. 1-11.

WHO. Dengue/DHF; Regional guidelines on dengue/DHF prevention and control. [online], , didapat dari ( http://www.searo.who.int/en/ Aug 2006. diunduh 11 februari 2011).

Zulkarnaen I, Nelwan RHH, Pohan HT, et al, 2001, Demam Berdarah Dengue, Ilmu Penyakit Dalam FKUI, Jakarta 
